\title{
Short communication: A new minicurd model system for hard cooked cheeses
}

\author{
M. A. Vélez, ${ }^{1}$ M. C. Perotti, S. R. Rebechi, and E. R. Hynes \\ Instituto de Lactología Industrial (INLAIN), Universidad Nacional del Litoral/Consejo Nacional de Investigaciones \\ Científicas y Técnicas (UNL/CONICET), Santiago del Estero 2829, Santa Fe, CP 3000, Argentina
}

\begin{abstract}
The aim of this study was to propose and validate a new minicurd model of young hard cheese. Curd particles and whey obtained from conventional cheese making of Reggianito Argentino were separated and frozen. Then, both fractions were thawed and the mixture of whey and curds was reconstituted, from which minicurds were made on the laboratory scale. Repeatability and the effect of freezing on minicurd composition were investigated by assessing $\mathrm{pH}$, protein and moisture contents, sodium chloride content, and total thermophilic lactic flora counts. Good repeatability was achieved, and no significant differences were found between minicurds made from fresh compared with frozen materials. Composition of the minicurd was appropriate for modeling Reggianito Argentino cheese. Key words: cheese-making technology, minicurd model, hard cheese
\end{abstract}

\section{Short Communication}

Cheese-making experiments aimed at assessing technological innovation or new additives or ingredients are expensive and time consuming. Consequently, several cheese models have been developed in which variations in the biochemistry of ripening or the cheese ecosystem can be assessed rapidly and without the complexity of a real-scale cheese matrix. Scientific research focused on technological changes in the food industry needs to be validated at the pilot scale because in vitro assays are usually not enough to inspire confidence and promote technological changes in the industry (Hunter et al., 1997). However, cheese model systems are useful in many applications. Available cheese models include miniature semi-hard or Cheddar cheeses, cheese slurries, and Ch-Easy (Farkye et al., 1995; Smit et al., 1995; Rehman et al., 1998; Jeanson et al., 2011; Milesi et al., 2011). Reggianito Argentino and Parmigiano Reggiano

Received September 27, 2014.

Accepted February 13, 2015.

${ }^{1}$ Corresponding author: mvelez@fiq.unl.edu.ar extracts have also been developed as a model of the aqueous phase of this type of cheese (Gatti et al., 2008; Bergamini et al., 2013). However, these models greatly differ from the composition of real cheeses. The aim of the present work was to find a model applicable to study biochemical activities naturally occurring in the cheese environment.

Examples of applications for these models include comparison of Lactobacillus strains, with or without glutamate dehydrogenase (GDH) activity, according to their ability to produce aroma compounds (Kieronczyk et al., 2004); assessment of lactic acid bacteria aminopeptidase activities (Gatti et al., 2008); culture of longripened cheese microflora (Neviani et al., 2009); and evaluation of proteolysis induced by different strains (Milesi et al., 2011).

The objective of the present work was to propose and validate a new cheese model for young hard-cooked cheeses, consisting of a reconstituted minicurd. We intended that its composition was appropriate for modeling Reggianito cheese; other requirements for the model were its cost effectiveness and simplified experimental manipulation. For that purpose, we chose a layout that included one standard cheese-making using $100 \mathrm{~L}$ of milk, which we stopped before final cooking of wheycurds. Curds and whey were separated at this point and became the raw materials for multiple minicurd preparations. Freezing of raw materials was also proposed.

Raw bulk milk (100 L), pH $6.65 \pm 0.05$, Dornic acidity $18 \pm 1^{\circ} \mathrm{D}\left(1^{\circ} \mathrm{D}=100 \mathrm{mg}\right.$ of lactic acid/L) was supplied by a local dairy plant (Milkaut Coop. Ltda, Franck, Santa Fe, Argentina) and standardized to $2.8 \%$ fat. Milk was batch pasteurized at $63^{\circ} \mathrm{C}$ for 30 min and cooled to $33^{\circ} \mathrm{C}$ for cheese making. Then, $\mathrm{CaCl}_{2}$ was added to a final concentration of $0.014 \% \mathrm{wt} / \mathrm{vol}$; $\mathrm{pH}$ was adjusted to 6.40 with lactic acid $(1.5 \% \mathrm{wt} /$ vol) because some acidification of the cheesemilk is required before coagulation in this type of cheese. Then, a mixed commercial starter of Lactobacillus helveticus and Lactobacillus bulgaricus (Chr. Hansen Argentina, Quilmes, Argentina) was added at a concentration of $10^{6} \mathrm{cfu} / \mathrm{mL}$ of milk. After $10 \mathrm{~min}$ of mechanical stirring, 
Maxiren 150 (100\% chymosin, Gist-Brocades, Seclin, France) was added at a final concentration of $0.012 \mathrm{~g} / \mathrm{L}$ to coagulate the milk. After 18 to $20 \mathrm{~min}$, the curd was cut to the required grain size (approximately half the size of a rice grain) by successive cuts under manual agitation. The mixture of curd particles and whey was continuously stirred at the coagulation temperature of $33^{\circ} \mathrm{C}$. Then, approximately $15 \mathrm{~kg}$ of the mixture of curd particles-whey was taken from the vat and separated in a sieve (2-mm mesh size). At this step, the curd particles were quite wet and undergoing syneresis, so the operation was performed as quickly as possible to avoid heterogeneity in moisture content, acidification, or the formation of a continuous coagulum. Curd particles and whey were packed separately in tight plastic bags $(2 \mathrm{~L})$ and frozen at $-18^{\circ} \mathrm{C}$ in 3 different freezers for their subsequent use. The proportion of curd and whey in the original mixture was assessed by mass balance: an aliquot of the thoroughly homogeneous mixture and its separate fractions were weighed. The proportion was 1:4 curd-to-whey.

One day before the minicurd preparations, the raw materials (whey and curds) were thawed at $4^{\circ} \mathrm{C}$. Curd particles were disaggregated and mixed with a spatula in order to take representative samples from the curd contained in the plastic bags. Curds and whey were tempered at $33^{\circ} \mathrm{C}$ for $20 \mathrm{~min}$ in a bath to simulate the conditions in the vat, and $\mathrm{pH}$ was measured by immersing a pH electrode (Metrohm, E 516 Titriskop, Herisau, Switzerland). Then, mixtures of $\sim 500 \mathrm{~g}$ of whey and curds were prepared in the same proportion as was found in the vat (1:4).

The mixtures were then incubated at $37^{\circ} \mathrm{C}$ until they reached a $\mathrm{pH}$ of 5.6; this intermediate $\mathrm{pH}$ value was chosen to approach the standard value commonly found in cheeses (5.4), thus avoiding the risk of overacidification. After that, the cooking step was performed: curds and whey were gently stirred while being heated in a bath at $1^{\circ} \mathrm{C} / \mathrm{min}$ up to $45^{\circ} \mathrm{C}$. After reaching $45^{\circ} \mathrm{C}$, the mixtures were heated more rapidly $\left(>1^{\circ} \mathrm{C} / \mathrm{min}\right)$ up to $50^{\circ} \mathrm{C}$. When the mixtures reached the desired curd scalding temperature, the stirring was stopped. The curds were separated from the whey by centrifugation (Multi RF; Thermo Scientific, Waltham, $\mathrm{MA}$ ) at $2,750 \times \mathrm{g}$ and $37^{\circ} \mathrm{C}$ for $20 \mathrm{~min}$ in 250 - $\mathrm{mL}$ tubes, using a swinging bucket rotor to obtain minicurds with a cylindrical shape. Minicurds were refrigerated for 5 min and brined in $20 \%(\mathrm{wt} / \mathrm{vol})$ brine at $12^{\circ} \mathrm{C}$ for 20 min. Four replicates were obtained from each batch of curd particles and whey. In each replicate, 2 minicurds of approximately $25 \mathrm{~g}$ were made in parallel; one was sampled immediately and the other was vacuum packed in plastic film and stored for $7 \mathrm{~d}$ at $12^{\circ} \mathrm{C}$. An example minicurd is shown in Figure 1.

We checked the repeatability of the model for raw materials coming from different Reggianito cheesemaking vats, made on different days, and with different milk. Temperature and $\mathrm{pH}$ curves were monitored in the curd-whey mixtures during minicurd preparation. Minicurds were analyzed in duplicate on d 1 (preparation) and $\mathrm{d} 7$, as follows: $\mathrm{pH}$ measured by American Public Health Association method (Bradley et al., 1992); proteins by the Kjeldahl method (IDF, 1993), moisture content by oven drying to a constant weight at $102 \pm 1^{\circ} \mathrm{C}$ according to IDF (1982), and sodium chloride by atomic absorption spectrophotometry (AOAC, 1990). Thermophilic lactic bacteria were assessed before storage by plating sample dilutions on skim milk agar and counting colonies after $48 \mathrm{~h}$ of incubation at $37^{\circ} \mathrm{C}$ (Candioti et al. 2002).

The effect of freezing and thawing of whey and curd particles on minicurd composition was also checked.
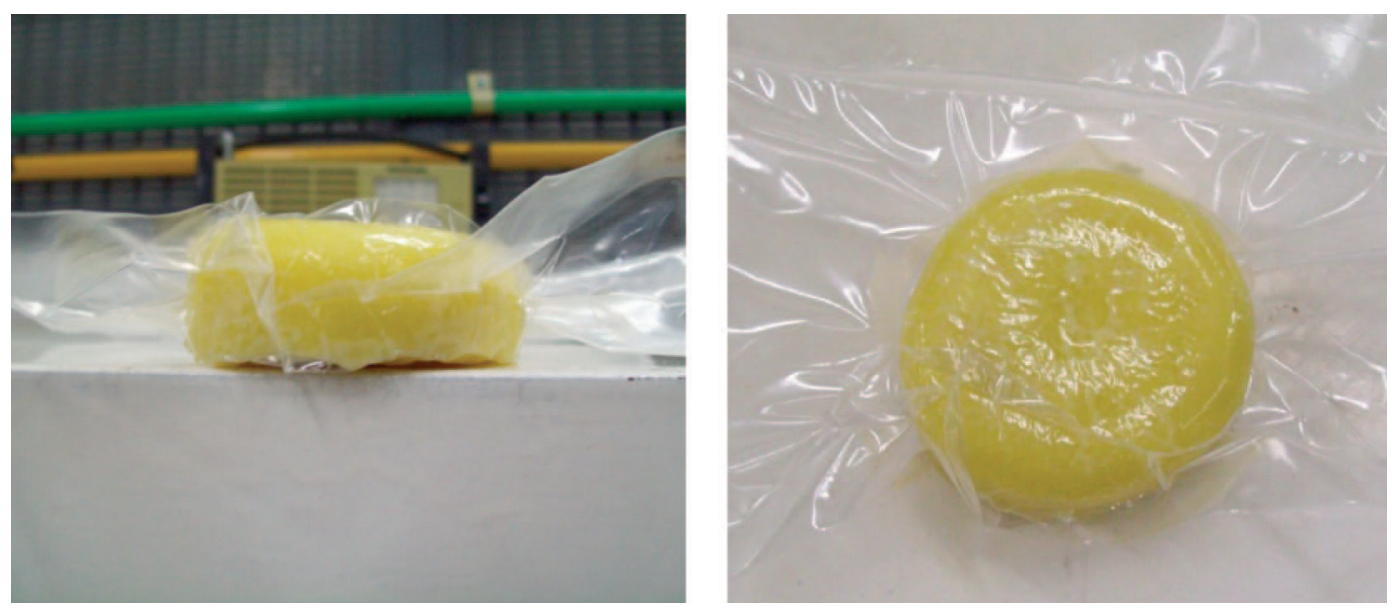

Figure 1. Example minicurd (25 g): (a) horizontal view, (b) top view. Color version available online. 


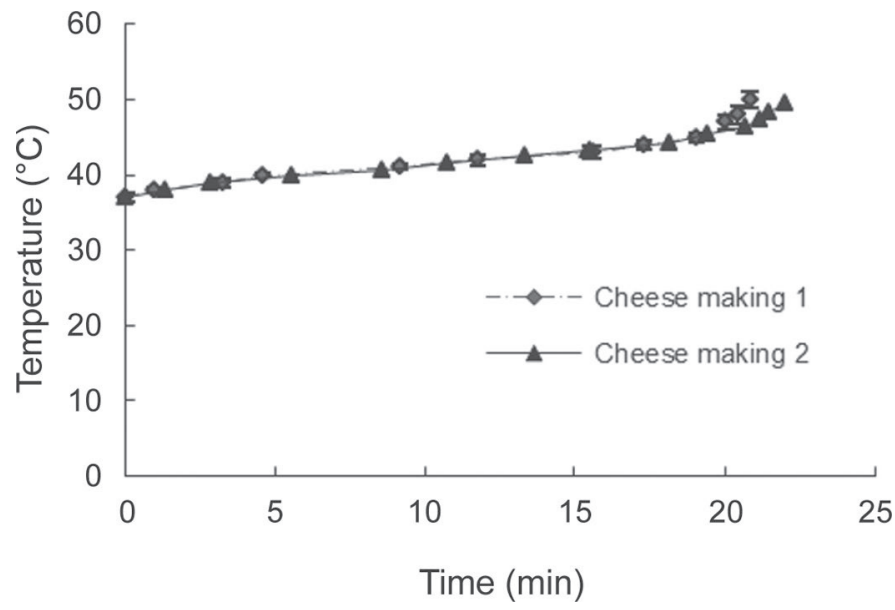

Figure 2. Temperature curves during preparation of minicurds. Each curve corresponds to average values of 4 replicate minicurds by cheese-making day. Temperature recording began at the end of the incubation $\left(37^{\circ} \mathrm{C}\right)$ of the curd-whey mixture.

Whey-curd mixtures were prepared with fresh materials from different Reggianito cheese vats and used to obtain 3 minicurd replicates. They were compared with minicurds made using frozen materials. As described above, 2 minicurds were made in parallel: one to sample on the day of curd making and the other to store for 7 d at $12^{\circ} \mathrm{C}$.

No significant differences were found in the temperature and $\mathrm{pH}$ curves (Figures 2 and 3 ) for minicurds made using frozen materials. We compared 2 groups of 4 replicate minicurds prepared from frozen raw materials provided by 2 cheese vats obtained on different days. Data for $\mathrm{pH}$ curves were recorded when the curd was being maintained at $37^{\circ} \mathrm{C}$ after thawing. Temperature monitoring began when the curd-whey mixture reached the end of the incubation step at $37^{\circ} \mathrm{C}$.

All samples were analyzed for microbial counts. Total thermophilic lactic flora exceeded $10^{8} \mathrm{cfu}$ at beginning of ripening in all curds (data not shown). The activity of the lactic starter in all minicurds was also evidenced by $\mathrm{pH}$ decrease.

For different cheese makings, mean values of $\mathrm{pH}$ and moisture, sodium chloride, and protein contents of minicurds did not show significant differences when a $t$ test was applied for each variable on d 0 and $d 7$ (Table $1)$. Good repeatability was verified; the coefficient of variation did not exceed $3 \%$.

It is known that simplifying the cheese matrix results in changes in some aspect: texture, chemical, or physical properties (Shakeel-ur-Rehman et al., 1998). In recent years, several attempts have been made to find an ideal cheese model, but the quality of a model is always related to the objectives of each investigation. In general, the composition of model acid curds and slurries differs greatly from that of a real cheese (Farkye et al., 1995; Choi et al., 2006; Yu et al., 2012). Choi et al. (2006) obtained curds with 90\% moisture and 3\% proteins; Farkye et al. (1995) obtained slurries of Cheddar cheeses with $57 \%$ moisture and $23 \%$ proteins; and the model proposed by Milesi et al. (2008) contained $\sim 61 \%$ moisture and 18\% proteins. Smit et al. (1995) prepared a cheese model, Ch-Easy, by heating a slurry at $80^{\circ} \mathrm{C}$, resulting in composition and texture similar to that of natural cheese; however, heat treatment would inactivate enzymes (coagulant, proteinases, and peptidases from starter or other sources), which would modify the natural environment present in cheese. In contrast to these earlier reports, we achieved a similar composition to young Reggianito cheeses in the present work. Our minicurds were stored for $7 \mathrm{~d}$, a short period aimed to represent the first stage of cheese ripening. We noticed that the $\mathrm{pH}$ decrease during storage was not significant, probably because of the small curd size and consequent rapid temperature decrease. Minicurd moisture content was similar to that found in hard cooked cheeses at the beginning of ripening (Battistotti and Corradini, 1993; Ramonda, 2009; Ceruti et al., 2012) but higher than levels found in cheeses ripened for $180 \mathrm{~d}$ (Candioti et al., 2002; Sihufe et al., 2007). In terms of sodium chloride content, the values obtained were acceptable for young Reggianito cheeses (Sihufe et al., 2007; Wolf et al., 2010; Ceruti et al., 2012).

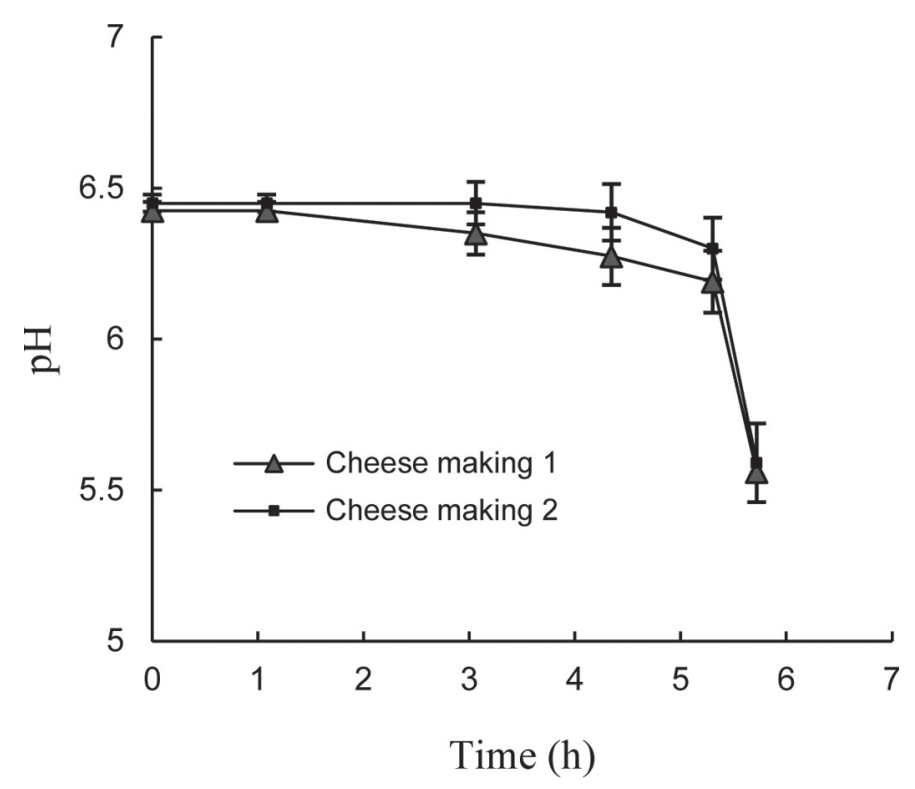

Figure 3. Acidification curves during preparation of minicurds made with frozen raw materials. Recording began when the curd-whey mixture reached the incubation temperature $\left(37^{\circ} \mathrm{C}\right)$ and continued until the end of manufacture. Symbols correspond to average values of 4 replicate minicurds for each cheese-making day. Error bars indicate SD. 
Table 1. Moisture, protein, and salt contents and $\mathrm{pH}$ of minicurds made with frozen raw materials (global mean and SD of 4 replicates are shown)

\begin{tabular}{lccccc}
\hline & \multicolumn{2}{c}{ Cheese making d 1} & & \multicolumn{2}{c}{ Cheese making d 2} \\
\cline { 2 - 3 } \cline { 5 - 6 } Item & Mean $\pm \mathrm{SD}$ & $\mathrm{CV}$ & & Mean $\pm \mathrm{SD}$ & $\mathrm{CV}$ \\
\hline 1 d ripening time & & & & $37.48^{\mathrm{a}} \pm 0.99$ & 1.95 \\
Moisture (\%) & $37.07^{\mathrm{a}} \pm 0.64$ & 1.54 & & $29.73^{\mathrm{a}} \pm 0.54$ & 2.66 \\
Proteins (\%) & $30.03^{\mathrm{a}} \pm 0.58$ & 1.74 & & $2.07^{\mathrm{a}} \pm 0.04$ & 1.93 \\
NaCl (S/M) & $2.00^{\mathrm{a}} \pm 0.06$ & 3.00 & & $5.59^{\mathrm{a}} \pm 0.10$ & 1.80 \\
pH & $5.56^{\mathrm{a}} \pm 0.09$ & 1.93 & & $38.2^{\mathrm{a}} \pm 1.17$ & 1.58 \\
d ripening time & & & & $30.48^{\mathrm{a}} \pm 0.70$ & 3.05 \\
Moisture (\%) & $37.75^{\mathrm{a}} \pm 0.64$ & 1.15 & & $2.11^{\mathrm{a}} \pm 0.02$ & 1.42 \\
Proteins (\%) & $29.96^{\mathrm{a}} \pm 0.4$ & 1.68 & & $5.55^{\mathrm{a}} \pm 0.09$ & 2.30 \\
NaCl (S/M) & $1.95^{\mathrm{a}} \pm 0.04$ & 2.05 & & \\
$\mathrm{pH}$ & $5.46^{\mathrm{a}} \pm 0.06$ & 1.34 & &
\end{tabular}

${ }^{a}$ Values in the same row with the same superscripts do not differ $(P<0.05)$.

${ }^{1} \mathrm{~S} / \mathrm{M}=$ salt in moisture.

We observed no differences in acidification curves for minicurds prepared from frozen versus fresh raw materials (Figure 4). For minicurds obtained from fresh materials, the incubation step at $37^{\circ} \mathrm{C}$ was not performed because it was not needed to restart acidification. In these curds, draining, $\mathrm{pH}$, and temperature increases followed the same temporal steps as Reggianito cheesemaking (Zalazar et al., 1999; Vélez et al., 2010). Composition of minicurds made with frozen and fresh raw materials was similar: $\mathrm{pH}$, moisture, sodium chloride, and protein content did not show significant differences. Microbiology counts exceeded $10^{8}$ cfu (Table 2). As far as we know, no information was reported about the effect of freezing bovine curd grains, but some similar results were found by Picon et al. (2010) and Campos et al. (2011), who studied cheeses made with frozen ewe and goat curds, respectively, as follows: curds were pressed, frozen, thawed, cut, and mixed with fresh cow milk to manufacture cheeses. Authors did not find differences in $\mathrm{DM}, \mathrm{pH}$, and microbiology counts between experimental and control cheeses. Freezing of curd from bovine milk, aimed at producing low-moisture Mozzarella, is a usual practice in Argentina and other countries in South America, mainly carried out in small dairies and farm factories. Curds are drained, frozen, and sold to Mozzarella factories that thaw them, ripen them to get the correct $\mathrm{pH}$, and stretch them continuing with the usual cheese-making process (Anuario de la Lechería, 2013).

In this work, we proposed a cheese model based on a minicurd reconstituted from frozen curd grains and whey obtained from standard Reggianito cheesemaking. We conclude that composition and acidification curves during minicurd making were not biased by either minicurd replicates or cheese batch elaboration; consequently, the model had good repeatability. The composition of minicurds made from curd grains and whey that had been previously frozen did not differ from that of minicurds made with fresh raw materials.

The model proposed has advantages compared with previous experimental models; the fact that raw materials were obtained after starter addition and that the curd was cut in the original vat (pilot plant scale) probably improved the simulation of a real cheese curd. Compared with other cheese models, minicurds were easier and quicker to obtain, and less expensive. Our model is versatile because it can be adapted to other cheese-making technologies.

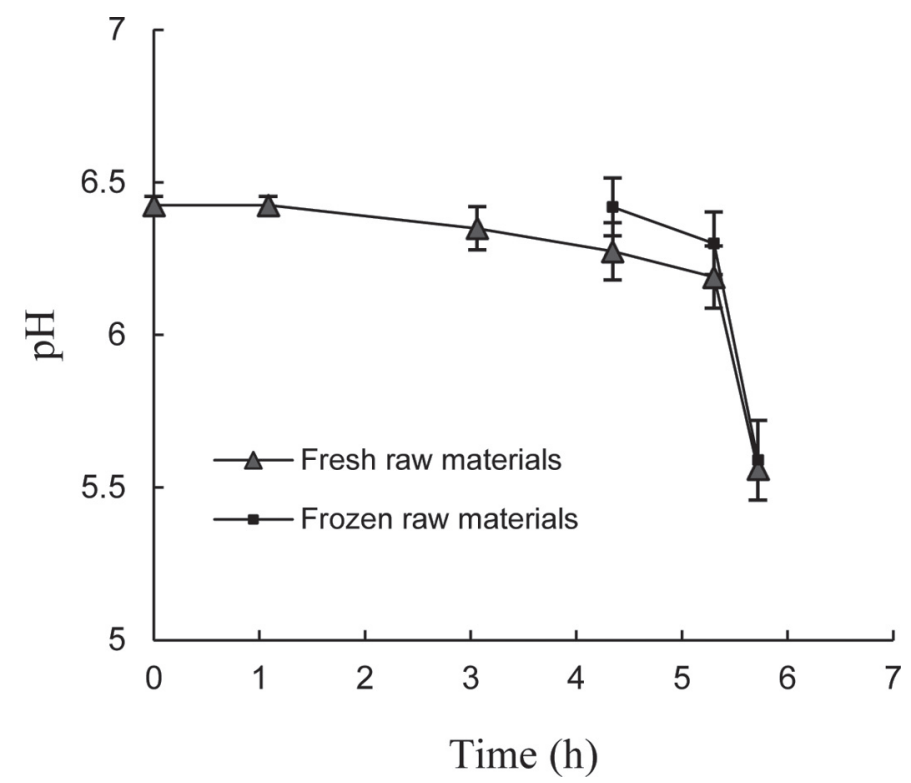

Figure 4. Acidification curves during preparation of minicurds made with frozen and fresh raw materials. Error bars indicate SD. 
Table 2. Moisture and protein contents, $\mathrm{pH}$, and microbial counts of minicurds made with frozen and fresh materials (global mean and SD of 3 replicates are shown) on d 1 and 7 of ripening

\begin{tabular}{|c|c|c|}
\hline Item & $\begin{array}{l}\text { Frozen } \\
\text { materials }\end{array}$ & $\begin{array}{l}\text { No frozen } \\
\text { materials }\end{array}$ \\
\hline \multicolumn{3}{|l|}{ Day 1} \\
\hline Moisture (\%) & $37.20^{\mathrm{a}} \pm 0.55$ & $38.00^{\mathrm{a}} \pm 1.5$ \\
\hline Proteins (\%) & $30.00^{\mathrm{a}} \pm 1.00$ & $31.5^{\mathrm{a}} \pm 0.70$ \\
\hline $\mathrm{pH}$ & $5.55^{\mathrm{a}} \pm 0.15$ & $5.40^{\mathrm{a}} \pm 0.20$ \\
\hline Total thermophilic lactic flora $(\mathrm{cfu} / \mathrm{mL})$ & $6 \times 10^{8}$ & $7.5 \times 10^{8}$ \\
\hline \multicolumn{3}{|l|}{ Day 7} \\
\hline Moisture (\%) & $37.50^{\mathrm{a}} \pm 0.70$ & $36.20^{\mathrm{a}} \pm 1.0$ \\
\hline Proteins $(\%)$ & $31.50^{\mathrm{a}} \pm 1.30$ & $32.00^{\mathrm{a}} \pm 0.8$ \\
\hline $\mathrm{pH}$ & $5.45^{\mathrm{a}} \pm 0.11$ & $5.50^{\mathrm{a}} \pm 0.15$ \\
\hline
\end{tabular}

${ }^{\text {a}}$ Values in the same row with the same superscripts do not differ $(P>0.05)$.

\section{REFERENCES}

Anuario de Lechería. 2013. Accessed Sep. 25, 2014. http://www.Portalechero.com/innovaportal/innova.front/mozzarella_a_partir_ de_masas_pre_maduradas.html.

AOAC. 1990. Official Methods of Analysis. Vol. II. Association of Official Analytical Chemists, Arlington, VA.

Battistotti, B., and C. Corradini. 1993. Italian cheese. Pages 221-244 in Cheese: Chemistry, Physics and Microbiology. Vol. 2. P. F. Fox, ed. Chapman \& Hall, London, UK.

Bergamini, C. V., G. H. Peralta, M. M. Milesi, and E. R. Hynes. 2013. Growth, survival, and peptidolytic activity of Lactobacillus plantarum I91 in a hard-cheese model. J. Dairy Sci. 96:5465-5476.

Bradley, R., Jr., E. Arnold, D. Barbano, R. Semerad, D. Smith, and B. Vines. 1992. Chemical and physical methods. Pages 433-532 in Standard Methods for the Examination of Dairy Products. R. Marshall, ed. American Public Health Association (APHA), Washington, DC.

Campos, G., L. Robles, R. Alonso, M. Nuñez, and A. Picon. 2011. Microbial dynamics during the ripening of a mixed cow and goat milk cheese manufactured using frozen goat milk curd. J. Dairy Sci. 94:4766-4776.

Candioti, M. C., E. R. Hynes, A. Quiberoni, S. B. Palma, N. Sabbag, and C. A. Zalazar. 2002. Reggianito Argentino cheese: Influence of Lactobacillus helveticus strains isolated from natural whey cultures on cheese making and ripening processes. Int. Dairy J. 12:923-931.

Ceruti, R. J., S. E. Zorrilla, and G. A. Sihufe. 2012. The influence of elevated initial ripening temperature on the proteolysis in Reggianito cheese. Food Res. Int. 48:34-40.

Choi, L. H., L. M. Were, and S. S. Nielsen. 2006. Effects of incubation temperature and salt concentration on plasminogen activators in cheese curd. Int. Dairy J. 16:609-618.

Farkye, N. Y., S. A. Madkor, and H. G. Atkins. 1995. Proteolytic abilities of some lactic acid bacteria in a model cheese system. Int. Dairy J. 5:715-725.

Gatti, M., J. De Dea Lindner, F. Gardini, G. Mucchetti, D. Bevacqua, M. E. Fornasari, and E. Neviani. 2008. A model to assess lactic acid bacteria aminopeptidase activities in Parmigiano Reggiano cheese during ripening. J. Dairy Sci. 91:4129-4137.

Hunter, E. A., D. A. McNulty, and J. M. Banks. 1997. Statistical design and analysis of experiments in cheese technology. Lebenson. Wiss. Technol. 30:121-128.

IDF (International Dairy Federation). 1982. Standard 4A: Cheese and processed cheese: determination of the total solids content. Reference method. IDF, Brussels, Belgium.

IDF (International Dairy Federation). 1993. Standard 20B: Milk: Determination of nitrogen content by Kjeldahl method. Reference Method. IDF, Brussels, Belgium.

Jeanson, S., J. Chadoeuf, M. N. Madec, S. Aly, J. Floury, T. F. Brocklehurst, and S. Lortal. 2011. Spatial distribution of bacterial colonies in a model cheese. Appl. Environ. Microbiol. 77:1493-1500.
Kieronczyk, A., S. Skeie, T. Langsrud, D. Le Bars, and M. Yvon. 2004. The nature of aroma compounds produced in a cheese model by glutamate dehydrogenase positive Lactobacillus INF15D depends on its relative aminotransferase activities towards the different amino acids. Int. Dairy J. 14:227-235.

Milesi, M. M., C. V. Bergamini, and E. Hynes. 2011. Production of peptides and free amino acids in a sterile extract describes peptidolysis in hard-cooked cheeses. Food Res. Int. 44:765-773.

Milesi, M. M., P. L. H. McSweeney, and E. Hynes. 2008. Viability and contribution to proteolysis of an adjunct culture of Lactobacillus plantarum in two model cheese systems: Cheddar cheese-type and soft-cheese type. J. Appl. Microbiol. 105:884-892.

Neviani, E., J. De Dea Lindner, V. Bernini, and M. Gatti. 2009. Recovery and differentiation of long ripened cheese microflora through a new cheese-based cultural medium. Food Microbiol. 26:240-245.

Picon, A., P. Gaya, E. Fernández-García, A. Rivas-Cañedo, M. Ávila and M. Nuñez. 2010. Proteolysis, lipolysis, volatile compounds, texture, and flavor of Hispánico cheese made using frozen ewe milk curds pressed for different times. J. Dairy Sci. 93:2896-2905.

Ramonda, M. B. 2009. Desarrollo de un modelo basado en métodos estadísticos para la predicción del tiempo de maduración de Quesos Argentinos. PhD Thesis. Facultad de Ingeniería Química, Universidad Nacional del Litoral, Santa Fe, Argentina.

Shakeel-ur-Rehman, , P. L. H. McSweeney, and P. F. Fox. 1998. Protocol for the manufacture of miniature cheeses. Lait 78:607-620.

Sihufe, G. A., S. E. Zorrilla, D. J. Mercanti, M. C. Perotti, C. A. Zalazar, and A. C. Rubiolo. 2007. The influence of ripening temperature and sampling site on the lipolysis in Reggianito Argentino cheese. Food Res. Int. 40:1220-1226.

Smit, G., A. Braber, W. Van Spronsen, G. Van Den Berg, and F. A. Exterkate. 1995. Ch-easy model: A cheese-based model to study cheese ripening. Pages 185-190 in Bioflavour 95. P. Étiévant and P Schreier, ed. Institut National de la Recherche Agronomique, Dijon, Paris, France.

Vélez, M. A., M. C. Perotti, I. V. Wolf, E. R. Hynes, and C. A. Zalazar. 2010. Influence of milk pretreatment in production of free fatty acids and volatile compounds in hard cheeses: Heat treatment \& mechanical agitation. J. Dairy Sci. 93:4545-4554.

Wolf, I. V., M. C. Perotti, S. M. Bernal, and C. A. Zalazar. 2010. Study of the chemical composition, proteolysis, lipolysis and volatile compounds profile of commercial Reggianito Argentino cheese: Characterization of Reggianito Argentino cheese. Food Res. Int. 43:1204-1211.

Yu, L., M. Ngadi, and V. Raghavan. 2012. Proteolysis of cheese slurry made from pulsed electric field-treated milk. Food Bioprocess Tech. 5:47-54.

Zalazar, C. A., C. A. Meinardi, and E. R. Hynes. 1999. Los quesos argentinos. Pages 20-49 in Quesos Típicos Argentinos. Una revisión general sobre producción y características. C. A. Zalazar, C. A. Meinardi, and E. R. Hynes, ed. Centro de Publicaciones. Universidad Nacional del Litoral, Santa Fe, Argentina. 